\title{
Determinan Sosial Ekonomi Konsumsi Minuman Berpemanis di Indonesia: Analisis Data Susenas 2017
}

\author{
Socio-economic Determinants of Sugar-Sweetened Beverages Consumption \\ in Indonesia: Analysis of Susenas 2017 Data
}

\author{
Widi Astutty Casimira Daeli', Atik Nurwahyuni² \\ ${ }^{1}$ Pascasarjana IImu Kesehatan Masyarakat, Fakultas Kesehatan Masyarakat, Universitas Indonesia \\ ${ }^{2}$ Departemen Administrasi dan Kebijakan Kesehatan, Fakultas Kesehatan Masyarakat, Universitas Indonesia \\ Korespondensi: Widi Astutty \\ e-mail:widi.casimira@gmail.com
}

\begin{abstract}
Abstrak
Sugar-Sweetened Beverages (SSBs) atau yang dikenal dengan minuman berpemanis bergula adalah cairan yang ditambahkan dengan berbagai macam bentuk gula. Konsumsi minuman berpemanis berlebih berkontribusi terhadap Penyakit Tidak Menular (PTM) seperti penambahan berat badan, meningkatkan risiko diabetes mellitus tipe 2 serta penyakit kardiovaskuler. PTM dapat dicegah sedini mungkin dengan mengurangi konsumsi kalori dalam gula. WHO menyarankan orang dewasa dan anak-anak untuk mengurangi asupan gula hingga kurang dari 10\% dari total asupan energi dan dilanjutkan hingga kurang dari 5\% dari total asupan energi. Artikel ini bertujuan untuk mengetahui determinan sosial ekonomi yang memengaruhi konsumsi minuman berpemanis. Menggunakan data sekunder dari survey sosial ekonomi nasional (Susenas) Tahun 2017 dengan model two part (OLS, Probit dan Tobit). Variabel akses internet merupakan variabel yang konsisten berhubungan dengan penurunan pengeluaran dan partisipasi rumah tangga untuk konsumsi minuman berpemanis. Oleh karena itu, perlu meningkatkan sosialisasi promosi iklan layanan kesehatan masyarakat terkait bahaya konsumsi minuman berpemanis berlebihan dan pencantuman batas aman konsumsi minuman berpemanis pada label kemasan.

Kata kunci : Minuman berpemanis, determinan sosial ekonomi, model two-part (OLS, Probit, dan Tobit)
\end{abstract}

\begin{abstract}
Sugar-Sweetened Beverages (SSBS) are added liquids with various of sugar. Consumption of SSBs contributes to Non-Communicable Diseases (NCDs) such as weight gain, increasing the risk of type 2 diabetes mellitus and cardiovascular diseases. NCDs can be prevented as early as possible by reducing the consumption of calories in sugar. WHO recommends adults and children to reduce sugar intake to less than $10 \%$ of total energy intake and continue to less than $5 \%$ of total energy intake. This study aims to determine the socio-economic factors consumption of SSBS. We employed secondary data from the 2017 National Socio-Economic Survey (Susenas) with two-part models (OLS, Probit and Tobit). We found that internet access is consistently associated with lower household expenditure and consumption of SSBS. Therefore, it is necessary to increase the promotion of public health service advertising related to the danger of excessive consumption of SSBs and the inclusion of safe consumption of SSBS on packaging labels.

Keywords: Sugar-sweetened beverages, socio-economic determinants, two-part models (OLS, Probit and Tobit)
\end{abstract}

\section{Pendahuluan}

Sugar-Sweetened Beverages (SSBs) atau minuman berpemanis bergula adalah cairan yang ditambahkan dengan berbagai macam bentuk gula seperti gula merah, berpemanis jagung, sirup jagung, dekstrosa, fruktosa, glukosa, sukrosa, dan bentuk gula lainnya. Jenis-jenis minuman berpemanis bergula seperti minuman buah, minuman olahraga, minuman energi, minuman pengganti elektrolit, dan minuman kopi dan teh yang telah ditambahkan gula (U.S. Department of Health and Human Services and U.S. Department of Agriculture, 2015; CDC, 2018).

Berdasarkan Laporan Hasil Studi Diet Total (SDT) di Indonesia pada Tahun 2014, konsumsi minuman dikelompokkan yaitu minuman serbuk dan minuman cairan. Penduduk Indonesia mengkonsumsi minuman serbuk rerata total sebesar 8,7 gram per orang per hari. Sedangkan rerata total konsumsi minuman cairan sebesar $25 \mathrm{ml} /$ orang/hari. Jenis minuman cairan yang paling tinggi di konsumsi adalah minuman kemasan sebesar 19,8 ml/orang/hari, minuman berkarbonasi sebesar 2,4 ml/orang/hari, dan minuman beralkohol sebesar $1 \mathrm{ml} /$ orang/hari (Siswanto dkk, 2014). World Health Organization (WHO) menyarankan orang dewasa dan anak-anak untuk mengurangi asupan gula hingga kurang dari $10 \%$ dari total asupan energi dan dilanjutkan hingga kurang dari 5\% dari total asupan energi (U.S. Department of Health and Human Services and U.S. 
Department of Agriculture, 2015; WHO, 2018d).

Penelitian di Amerika pada tahun 2017 menyebutkan bahwa konsumsi minuman berpemanis memiliki kontribusi menambah berat badan, meningkatkan risiko diabetes mellitus tipe 2 dan penyakit kardiovaskuler (Hu dan Malik, 2010). Di Indonesia, penelitian yang dilakukan Ramadhani dan Mahmudiono (2018) menyatakan bahwa konsumsi minuman berpemanis berhubungan dengan kejadian diabetes mellitus pada lansia dengan OR sebesar 9,375.

Penyakit tidak menular menyebabkan kematian sebanyak 41 juta dari 57 juta orang per tahun atau setara dengan $71 \%$ dari seluruh kematian secara global. Rentang usia 30-69 tahun merupakan usia dengan kematian akibat penyakit tidak menular sebanyak 15 juta orang setiap tahunnya. Kematian dini lebih dari $85 \%$ akibat penyakit tidak menular terjadi di negara-negara berpenghasilan rendah dan menengah (WHO, 2018a). Kematian akibat penyakit tidak menular di Indonesia diperkirakan sebesar 73\% dari seluruh kematian. Proporsi kematian akibat penyakit tidak menular paling tinggi di Indonesia adalah penyakit kardiovaskular sebanyak 35\%, kanker sebanyak $12 \%$, penyakit pernapasan kronik sebanyak $6 \%$, diabetes sebanyak $6 \%$, penyakit tidak menular lainnya sebanyak 15\%, kondisi maternal, perinatal dan kondisi nutrisi sebanyak $21 \%$, dan akibat cedera sebanyak 6\% (WHO, 2018b).

Secara global pada tahun 2016, orang dewasa yang mengalami kelebihan berat badan sebanyak lebih dari 1,9 miliar jiwa dan obesitas sebanyak lebih dari 650 juta jiwa. Usia 18 tahun ke atas yang mengalami kelebihan berat badan sebesar 39\% dan obesitas sebesar 13\%. Sedangkan usia di bawah 5 tahun yang mengalami kelebihan berat badan atau obesitas sebanyak 41 juta jiwa dan usia 5-19 tahun yang mengalami kelebihan berat badan atau obesitas sebanyak lebih dari 340 juta jiwa (WHO, 2018c). Di Indonesia, penduduk yang memiliki prevalensi obesitas yang masuk kategori IMT $\geq 25$ - 27 dan IMT $\geq 27$ adalah sebesar $33.5 \%$ dan kategori IMT $\geq 27$ sebesar 20,7\% (Kemenkes RI, 2018).

Melakukan pencegahan untuk mengurasi kelebihan berat badan dan obesitas merupakan hal penting. Oleh karena melakukan intervensi yang tepat untuk mendukung mengurangi konsumsi minuman berpemanis perlu dilakukan untuk mengetahui faktor-faktor yang memengaruhi konsumsi minuman berpemanis. Penelitian ini bertujuan untuk mengetahui determinan sosial ekonomi yang memengaruhi pengeluaran rumah tangga untuk konsumsi minuman berpemanis di Indonesia.

\section{Metode Penelitian}

Penelitian ini menggunakan data sekunder berasal dari hasil survey sosial ekonomi nasional (Susenas) tahun 2017. Susenas 2017 terdiri dari data hasil kuesioner pokok anggota rumah tangga dan data hasil kuesioner keterangan konsumsi/ pengeluaran makanan dan bukan makanan, dan pendapatan/ penerimaan rumah tangga di Indonesia. Batasan penelitian ini adalah rumah tangga yang memiliki pengeluaran minuman berpemanis yang termasuk dalam kelompok makanan dan minuman jadi dengan kode 222-226 dan kriteria eksluski rumah tangga yang tidak mengisi pengeluaran rumah tangga (missing value).

Variabel pengeluaran untuk konsumsi minuman berpemanis merupakan variabel dependen yang terbatas (Limited Dependent Variable) artinya variabel ini bersifat kontinyu dimana sebagian besar distribusi memiliki nilai nol (Gujarati, 2004). Variabel independen dalam penelitian ini adalah usia kepala keluarga, jenis kelamin kepala keluarga, status perkawinan kepala keluarga, pendidikan kepala keluarga, wilayah tempat tinggal kepala keluarga, status ekonomi, dan akses internet serta tujuan akses internet diambil dari data hasil kuesioner pokok anggota rumah tangga. Unit penelitian ini adalah rumah tangga. Responden pada penelitian ini menggunakan total sampling sebanyak 279.331 rumah tangga. Analisis yang digunakan adalah analisis two-part model antara Ordinary Least Square (OLS), Probit dan Tobit yang merupakan regresi linier berganda. Software yang digunakan adalah STATA 15 dan aplikasi MS.Word.

Persamaan regresi OLS yang digunakan adalah sebagai berikut:

$\mathrm{Y}=\beta_{0}+\beta_{1} \mathrm{usia}+\beta_{2} \mathrm{jk}+\beta_{3} \mathrm{kwn}+\beta_{4} \mathrm{ddk}+\beta_{5} \mathrm{krj}+$ $\beta_{6}$ wlyh $+\beta_{6}$ statekon $+\beta_{7}$ aksesnet $+\beta_{8}$ tujaksesnet $+\mu$

\section{Keterangan :}

Y : konsumsi minuman berpemanis, pengeluaran rumah tangga untuk mengkonsumsi minuman berpemanis( $\mathrm{Rp})$

$\beta_{0} \quad$ : konstanta

$\beta_{1}, \beta_{2}, \beta_{3}, \beta_{4}, \beta_{5}, \beta_{6}, \beta_{7}$ : Parameter

usia : usia kepala keluarga

jk : jenis kelamin kepala keluarga

( 0 =perempuan, 1 = laki-laki)

kwn : status perkawinan kepala keluarga 


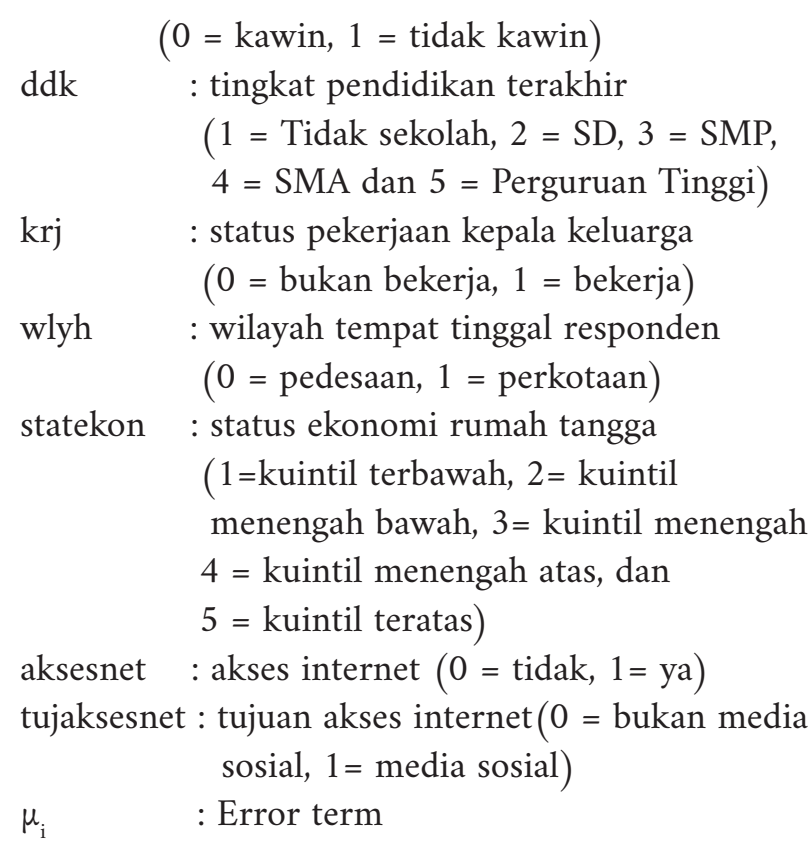

\section{Model Probit}

Model probit merupakan salah satu alternatif model LPM (Liniear Probability Model) dengan variabel dependen bersifat biner yaitu nilai 0 dan 1 . Model probit merupakan model yang menggunakan fungsi peluang normal kumulatif (Gujarati, 2004). Variabel Y pada penelitian ini merupakan variabel konsumsi minuman manis, dimana $\mathrm{Y}=1$ adalah rumah tangga yang mempunyai pengeluran untuk mengkonsumsi minuman manis dan $\mathrm{Y}=0$ adalah rumah tangga yang tidak mempunyai pengeluaran untuk mengkonsumsi minuman manis. Berikut ini adalah persamaan model dari probit menurut Gujarati (2004):

$$
\mathrm{P}=\mathrm{P}(\mathrm{Y}=1 \mid \mathrm{X})=\mathrm{P}\left(\mathrm{t}_{\mathrm{i}}^{*} \leq \mathrm{I}_{1}\right)=\mathrm{P}\left(\mathrm{Z}_{\mathrm{i}} \leq \beta_{1}+\beta_{2} \mathrm{X}_{\mathrm{i}}\right)=\mathrm{F}\left(\beta_{1}+\beta_{2} \mathrm{X}_{\mathrm{i}}\right)
$$

$\mathrm{P}\left(\mathrm{Yv} \_\right.$manis $\left.=1\right)=\beta_{0}+\beta_{1} \mathrm{usia}+\beta_{2} \mathrm{jk}+\beta_{3} \mathrm{kwn}+\beta_{4} \mathrm{~d}-$ $\mathrm{dk}+\beta_{5} \mathrm{krj}+\beta_{6}$ wlyh $+\beta_{6}$ statekon $+\beta_{7}$ aksesnet + $\beta_{8}$ tujaksesnet $+\mu$

\section{Model Tobit}

Tobit merupakan model regresi dengan nilai variabel dependen mempunyai sebagian besar nilai bersifat diskrit (data yang bernilai nol) dan sebagian lagi adalah data kontinyu. Survei konsumsi/pengeluaran rumah tangga sering ditemui data tersensor, termasuk konsumsi minuman manis di data Susenas 2017. Sebagian besar rumah tangga tidak mengkonsumsi minuman manis. Salah satu interpretasi bahwa nol adalah pengamatan tersensor dengan persamaan sebagai berikut (Trivedi, 2009): $y_{i}^{*}=x_{i}^{*} \beta+\varepsilon_{i}, i=1,2, \cdots, N$

Nilai probalilitas dari pengamatan yang disensor yaitu:

$$
\operatorname{Pr}\left(y_{i}^{*} \leq 0\right)=\operatorname{Pr}\left(x_{i}^{*} \beta+\varepsilon \leq 0=\phi\left\{\frac{0-x_{j}^{*} \beta}{\sigma}\right\}\right.
$$

dimana $\phi$ merupakan nilai standar distribusi kumulatif normal. Untuk kasus data yang tersensor kiri dengan fungsi density yang memiliki dua komponen sesuai, menunjukkan nilai nol merupakan observasi yang disensor, sehingga nilai yang diharapkan dari model regresi tobit:

\section{Model Two Part}

Pendekatan model two-part merupakan kombinasi dua model dengan menetapkan model pertama untuk mekanisme sensor dan model kedua untuk hasil dari model pertama yang diamati (Trivedi, 2009). Model two-part cocok untuk model dengan pilihan biner untuk mengamati probabilitas hasil positif dan nilai nol dan kemudian dilanjutkan dengan model regresi untuk hasil yang benar-benar positif dari model biner (Belotti dkk, 2015). Pada penelitian ini, model yang digunakan adalah model probit untuk melihat probabilitas pengeluaran rumah tangga untuk konsumsi minuman berpemanis dan dilanjutkan dengan model regresi OLS yang merupakan analisis lanjutan untuk menganalisis rumah tangga yang benar-benar memiliki pengeluaran untuk mengkonsumsi minuman berpemanis. Model tobit digunakan untuk melihat gambaran pengeluaran rumah tangga dalam rupiah untuk konsumsi minuman berpemanis.

\section{Hasil}

Tabel 1 menunjukkan terdapat 187.691 rumah tangga $(67,19 \%)$ yang memiliki pengeluaran untuk konsumsi minuman berpemanis dari total responden yaitu 279.331 rumah tangga. Rerata usia kepala keluarga adalah 47 tahun. Sebagian besar kepala keluarga berjenis kelamin laki-laki yaitu 240.289 rumah tangga (86,02\%) dan sebanyak 228.425 rumah tangga $(81,78 \%)$ memiliki kepala keluarga berstatus kawin. Kepala keluarga dengan kategori tidak sekolah sebanyak 52.492 rumah tangga (18,79\%), SD sebanyak 88.082 rumah tangga (31,53\%), SMP sebanyak 45.470 (16,28\%) rumah tangga, SMA sebanyak 69.419 rumah tangga (24,85\%), perguruan tinggi sebanyak 23.868 rumah tangga $(8,54 \%)$.

Responden di kota yaitu sebanyak 155.224 rumah tangga (55,57\%). Status ekonomi pada kuintil 1 memiliki rerata pengeluaran perkapita 
Tabel 1 Distribusi Sosial Ekonomi Rumah Tangga di Indonesia Tahun 2017

\begin{tabular}{|c|c|c|c|c|c|c|}
\hline Variabel & Frekuensi (n) & $\begin{array}{c}\text { Persentase } \\
(\%)\end{array}$ & Rerata & SD & Min & Maks \\
\hline \multicolumn{7}{|l|}{ Variabel Dependen } \\
\hline \multicolumn{7}{|c|}{ Pengeluaran untuk konsumsi minuman berpemanis } \\
\hline Ya & 187.691 & 67,19 & 0,72 & 0,45 & 0 & 1 \\
\hline Tidak & 91.640 & 32,81 & & & & \\
\hline \multicolumn{7}{|c|}{ Variabel Independen } \\
\hline Usia & 279.331 & 100 & 47,00 & 13,54 & 11 & 97 \\
\hline \multicolumn{7}{|l|}{ Jenis Kelamin } \\
\hline Laki-laki & 240.289 & 86,02 & 0,86 & 0,34 & 0 & 1 \\
\hline Perempuan & 39.042 & 13,98 & & & & \\
\hline \multicolumn{7}{|l|}{ Status Perkawinan } \\
\hline Kawin & 228.425 & 81,78 & 0,82 & 0,39 & 0 & 1 \\
\hline Tidak kawin & 50.906 & 18,22 & & & & \\
\hline \multicolumn{7}{|l|}{ Pendidikan } \\
\hline Tidak Sekolah & 52.492 & 18,79 & 2,74 & 1,24 & 1 & 5 \\
\hline SD & 88.082 & 31,53 & & & & \\
\hline SMP & 45.470 & 16,28 & & & & \\
\hline SMA & 69.419 & 24,85 & & & & \\
\hline Perguruan Tinggi & 23.868 & 8,54 & & & & \\
\hline \multicolumn{7}{|l|}{ Status Pekerjaan } \\
\hline Bekerja & 243.510 & 87,18 & 0,87 & 0,34 & 0 & 1 \\
\hline Selain Bekerja & 35.821 & 12,82 & & & & \\
\hline \multicolumn{7}{|c|}{ Wilayah Tempat Tinggal } \\
\hline Perkotaan & 124.107 & 44,43 & 0,54 & 0,50 & 0 & 1 \\
\hline Pedesaan & 155.224 & 55,57 & & & & \\
\hline \multicolumn{7}{|c|}{ Status Ekonomi : Rata-rata pengeluaran } \\
\hline Kuintil 1 & 55.867 & 20,0 & $371.266,7$ & $78.074,5$ & $88.970,2$ & $491.264,3$ \\
\hline Kuintil 2 & 55.866 & 20,0 & $596.973,6$ & $63.095,2$ & $491.264,9$ & $710.756,0$ \\
\hline Kuintil 3 & 55.866 & 20,0 & $850.257,5$ & $86.356,5$ & $710.764,9$ & 1.009 .274 \\
\hline Kuintil 4 & 55.866 & 20,0 & $1.225 .516,9$ & $142.249,3$ & 1.009 .282 & 1.509 .452 \\
\hline Kuintil 5 & 55.866 & 20,0 & $2.550 .420,7$ & 1.556 .831 & 1.509 .472 & $>1.509 .472$ \\
\hline \multicolumn{7}{|l|}{ Akses Internet } \\
\hline Ya & 57.898 & 20,73 & 0,25 & 0,43 & 0 & 1 \\
\hline Tidak & 221.433 & 79,27 & & & & \\
\hline \multicolumn{7}{|c|}{ Tujuan Akses Internet } \\
\hline Ya & 57.898 & 20,73 & 0,20 & 0,40 & 0 & 1 \\
\hline Tidak & 221.433 & 79,27 & & & & \\
\hline
\end{tabular}

sebesar Rp 371.266,71, dan pada kuintil 5 mengakses internet, sebanyak 45.380 rumah tangga memiliki rerata pengeluaran perkapita sebesar Rp (16,25\%) mengakses internet untuk media sosial 2.550.420,7. Sebagian besar rumah tangga yang dan 233.951 rumah tangga (83,75\%) mengakses menjadi responden tidak pernah mengakses internet internet selain untuk media sosial. yaitu sebanyak 221.433 rumah tangga (79,27\%) Hasil Analisis Ordinary Least Square (OLS) dan sebanyak 57.898 rumah tangga (20,73\%) Pada analisis ini, yang termasuk dalam jumlah pernah mengakses internet. Jika dilihat tujuan dalam responden adalah rumah tangga yang memiliki 
pengeluaran konsumsi minuman berpemanis.

Tabel 2 Analisis OLS Pengeluaran Konsumsi Minuman Berpemanis Rumah Tangga di Indonesia Tahun 2017

\begin{tabular}{lccc}
\hline \multirow{2}{*}{\multicolumn{1}{c}{ Variabel }} & Koefisien & $\begin{array}{c}\text { S t a n d a r } \\
\text { Eror }\end{array}$ & Nilai t \\
\cline { 3 - 4 } & & Robust & Robust \\
\hline Usia & 77,01 & 5,86 & 13,14 \\
Jenis Kelamin & 2668,74 & 315,02 & 8,47 \\
Status Perkawinan & 1518,02 & 287,32 & 5,28 \\
Tingkat Pendidikan & & & \\
SD & 267,14 & 183,21 & 1,46 \\
SMP & 393,73 & 221,03 & 1,78 \\
SMA & 182,38 & 230,56 & 0,79 \\
Perguruan Tinggi & 2078,38 & 395,70 & 5,25 \\
Status Pekerjaan & 1664,54 & 238,92 & 6,97 \\
Tempat Tinggal & 245,51 & 119,57 & 2,05 \\
Status Ekonomi & & & \\
Kuintil 1 & $-8412,88$ & 138,90 & $-60,57$ \\
Kuintil 2 & $-4058,57$ & 147,07 & $-27,60$ \\
Kuintil 4 & 4168,46 & 190,10 & 21,93 \\
Kuintil 5 & 12243,43 & $3.980,07$ & 3,70 \\
Akses internet & $-442,86$ & 350,19 & $-1,26$ \\
Tujuan akses inter- & $-12,72$ & 371,65 & $-0,03$ \\
net & & & 18,61 \\
Konstanta & 8753,11 & 470,34 & \\
Prob>F & & 0,0000 & \\
Jumlah Responden & & 187.691 & \\
R ${ }^{2}$ & & 0,1184 & \\
\hline
\end{tabular}

$\mathrm{Y}=8753,11+77,01 \mathrm{usia}+2668,74 \mathrm{jk}+$ $1518,02 \mathrm{kwn}+267,14 \mathrm{ddk}_{1}+393,73 \mathrm{ddk}_{2}+$ $182,38 \mathrm{ddk}_{3}+2078,38 \mathrm{ddk}_{4}+1664,54 \mathrm{krj}+$ 245,51 wlyh - 8412,88statekon $1-4058,57$ state kon $_{2}+4168,46$ statekon $_{4}+12243,43$ statekon $_{5}$ 442,86aksesnet $-12,72$ tujaksesnet $+\mu$

Sebanyak 187.691 rumah tangga memiliki pengeluaran konsumsi minuman berpemanis. Semakin tinggi usia kepala keluarga akan memiliki pengeluaran lebih tinggi sebesar 77,01. Laki-laki memiliki pengeluaran lebih besar dibandingkan perempuan sebesar 2668,74. Kepala keluarga yang berstatus kawin memiliki pengeluaran lebih besar 1518,02 daripada yang berstatus tidak kawin. Berdasarkan tingkat pendidikan dibandingkan dengan tidak bersekolah, kepala keluarga dengan pendidikan SD, SMP, SMA, dan perguruan tinggi memiliki pengeluaran lebih besar masing-masing
267,14; 393,73; 182,38; dan 2078,38. Kepala keluarga yang bekerja memiliki pengeluaran lebih besar 1664,54 dibandingkan dengan yang bukan bekerja. Responden di perkotaan memiliki pengeluaran lebih besar 245,51 daripada di pedesaan.

Menurut status ekonomi, jika dibandingkan dengan kuintil 3, responden di kuintil 1 dan kuintil 2 memiliki pengeluaran untuk konsumsi minuman berpemanis lebih rendah secara berurutan 8412,88 dan 4058,57. Berbeda dengan kepala keluarga di kuintil 4 dan kuintil 5 memiliki pengeluaran lebih besar secara berurutan 4168,46 dan 12243,43. Rumah tangga yang pernah mengakses internet memiliki pengeluaran lebih rendah 442,86 dibandingkan dengan yang tidak pernah. Demikian pula, rumah tangga yang mengakses internet untuk akses media sosial memiliki pengeluaran lebih rendah 12,72 dibandingkan bukan untuk media sosial.

\section{Model Probit}

Berdasarkan Tabel 3, setiap kenaikan 1 tahun usia kepala keluarga memiliki probabilitas pengeluaran konsumsi minuman berpemanis 0,4\% lebih kecil. Laki-laki memiliki probabilitas 19,1\% meningkatkan pengeluaran daripada perempuan. Probabilitas kepala keluarga yang berstatus kawin sebesar 13,9\% meningkatkan pengeluaran dibandingkan berstatus tidak kawin. Probabilitas kepala keluarga dengan pendidikan SD, SMP, dan SMA secara berurutan 9,8\%; 8\%; dan 3,1\% meningkatkan pengeluaran dibandingkan tidak bersekolah. Sedangkan kepala keluarga dengan pendidikan perguruan tinggi memiliki probabilitas $0,5 \%$ menurunkan pengeluaran daripada yang tidak bersekolah.

Probabilitas kepala keluarga yang bekerja sebesar 23,3\% meningkatkan pengeluaran konsumsi minuman berpemanis dibandingkan dengan yang bukan bekerja. Wilayah perkotaan memiliki probabilitas $9,6 \%$ meningkatkan pengeluaran dibandingkan pedesaan. Berdasarkan status ekonomi jika dibandingkan dengan kuintil 3, kuintil 1 dan kuintil 2 masing-masing memiliki probabilitas 15,8\% dan $4 \%$ menurunkan pengeluaran, sedangkan kuintil 4 dan 5 secara berurutan memiliki probabilitas 13\% dan 24\% meningkatkan pengeluaran. Rumah tangga yang pernah mengakses internet memiliki probabilitas $16 \%$ menurunkan pengeluaran dibandingkan tidak pernah mengakses internet. Rumah tangga yang mengakses internet untuk media sosial memiliki probabilitas $78 \%$ meningkatkan pengeluaran dibandingkan bukan untuk media sosial. 
Tabel 3. Probit Model untuk Pengeluaran Rumah Tangga

untuk Konsumsi Minuman Berpemanis di Indonesia Tahun 2017

\begin{tabular}{|c|c|c|c|c|}
\hline \multirow{3}{*}{ Variabel } & \multicolumn{4}{|c|}{ Partisipasi (Probit) } \\
\hline & \multicolumn{2}{|c|}{ Probit } & \multicolumn{2}{|c|}{ Marginal Effect } \\
\hline & Koefisien & Standar Eror & $\mathrm{dy} / \mathrm{dx}$ & Standar Eror \\
\hline Usia & $-0,004$ & 0,0003 & $-0,001$ & 0,0001 \\
\hline Jenis Kelamin & 0,191 & 0,0148 & 0,065 & 0,0040 \\
\hline Status Perkawinan & 0,139 & 0,0136 & 0,049 & 0,0036 \\
\hline \multicolumn{5}{|l|}{ Tingkat Pendidikan } \\
\hline SD & 0,098 & 0,0104 & 0,029 & 0,0026 \\
\hline SMP & 0,080 & 0,0127 & 0,026 & 0,0031 \\
\hline SMA & 0,031 & 0,0123 & 0,012 & 0,0030 \\
\hline Perguruan Tinggi & $-0,005$ & 0,0174 & $-0,0003$ & 0,004 \\
\hline Status Pekerjaan & 0,232 & 0,0112 & 0.073 & 0,003 \\
\hline $\begin{array}{l}\text { Wilayah Tempat Ting- } \\
\text { gal }\end{array}$ & 0,096 & 0,0077 & 0,241 & 0,002 \\
\hline \multicolumn{5}{|l|}{ Status Ekonomi } \\
\hline Kuintil 1 & $-0,158$ & 0,0111 & $-0,061$ & 0,0029 \\
\hline Kuintil 2 & $-0,040$ & 0,0112 & $-0,009$ & 0,0029 \\
\hline Kuintil 4 & 0,013 & 0,0114 & 0,001 & 0,0029 \\
\hline Kuintil 5 & 0,024 & 0,0124 & $-0,005$ & 0,0031 \\
\hline Akses internet & $-0,016$ & 0,0188 & 0,010 & 0,0047 \\
\hline Tujuan akses internet & 0,078 & 0,0192 & 0,037 & 0,0047 \\
\hline Jumlah Responden & \multicolumn{4}{|c|}{279.331} \\
\hline Prob $>$ Chi & \multicolumn{4}{|c|}{0,0000} \\
\hline Pseudo $\mathrm{R}^{2}$ & \multicolumn{4}{|c|}{0,0201} \\
\hline Marginal effect & \multicolumn{4}{|c|}{0,0203} \\
\hline
\end{tabular}

Analisis probit menghasilkan nilai sensitifitas dan spesifisitas. Nilai sensitifitas sebesar $65,24 \%$ artinya kemampuan variabel independen memprediksi variabel dependen yang benar-benar mengkonsumsi minuman berpemanis secara benar sebesar 65,24\% dan nilai spesifisitas sebesar $48,46 \%$ artinya kemampuan variabel independen memprediksi variabel dependen yang tidak mengkonsumsi minuman berpemanis secara benar sebesar 48,46\% serta nilai correctly classified sebesar 59,74\% artinya nilai kemampuan model menyatakan secara benar adalah 59,74\% dengan nilai cut off klasifikasi prediksi sebesar 0,67.

\section{Model Tobit}

Berdasarkan model tobit pada Tabel 4 dapat diketahui nilai aktual pengeluaran rerata konsumsi minuman berpemanis. Setiap kenaikan 1 tahun usia kepala keluarga maka rerata pengeluaran meningkat Rp 10,60. Laki-laki memiliki rerata pengeluaran lebih besar daripada perempuan sebesar $\mathrm{Rp}$ 4.596,42. Sama halnya dengan status perkawinan, kepala keluarga yang berstatus kawin memiliki rerata pengeluaran lebih besar Rp 3.692,61 daripada yang berstatus tidak kawin.

Menurut tingkat pendidikan dibandingkan tidak bersekolah, pengeluaran rerata lebih tinggi pada tingkat SD sebesar Rp 1.489,78; SMP sebesar Rp 1.344,25; SMA sebesar $\mathrm{Rp} 801,44$; dan perguruan tinggi sebesar $\mathrm{Rp}$ 1.334,49. Apabila dibandingkan dengan kuintil 3 , rerata pengeluaran di kuintil 1 lebih rendah sebesar Rp 8.623,36, demikian pula kuintil 2 sebesar Rp 3420,41. Sedangkan kuintil 4 dan 5 masing-masing memiliki pengeluaran rerata lebih besar sebesar Rp 2.971,49 dan Rp 8.885,47.

Responden di perkotaan rerata pengeluaran lebih besar untuk konsumsi minuman berpemanis yaitu Rp 2.264,76 daripada pedesaan. Rumah tangga yang pernah mengakses internet memiliki rerata 
Tabel 4 Tobit Model untuk Pengeluaran Rumah Tangga untuk Konsumsi Minuman Berpemanis di Indonesia Tahun 2017

\begin{tabular}{|c|c|c|c|}
\hline \multirow[b]{2}{*}{ Variabel } & \multicolumn{3}{|c|}{ Regresi Tobit } \\
\hline & Koefisien & $\begin{array}{l}\text { Standar } \\
\text { Eror }\end{array}$ & Nilai t \\
\hline Usia & 10,60 & 4,71 & 2,25 \\
\hline Jenis Kelamin & 4596,42 & 229,28 & 20,05 \\
\hline Status Perkawinan & 3692,61 & 206,30 & 17,90 \\
\hline \multicolumn{4}{|l|}{ Tingkat Pendidikan } \\
\hline SD & 1489,78 & 156,38 & 9,53 \\
\hline SMP & 1344,25 & 185,99 & 7,23 \\
\hline SMA & 801,44 & 179,50 & 4,46 \\
\hline Perguruan Tinggi & 1334,49 & 249,47 & 5,35 \\
\hline Status Pekerjaan & 4367,92 & 176,19 & 24,79 \\
\hline Wilayah Tempat Tinggal & 2264,76 & 113,57 & 19,94 \\
\hline \multicolumn{4}{|l|}{ Status Ekonomi } \\
\hline Kuintil 1 & $-8623,36$ & 167,59 & $-51,46$ \\
\hline Kuintil 2 & $-3420,41$ & 164,69 & $-20,77$ \\
\hline Kuintil 4 & 2971,49 & 164.41 & 18,07 \\
\hline Kuintil 5 & 8885,47 & 176,28 & 50,41 \\
\hline Akses internet & 478,32 & 268,22 & 1,78 \\
\hline Tujuan akses internet & 1705,72 & 274,29 & 6,22 \\
\hline Konstanta & $-6990,56$ & 383,52 & $-18,23$ \\
\hline Prob $>$ Chi & & 0,0000 & \\
\hline Jumlah Responden & & 279.331 & \\
\hline Pseudo $\mathrm{R}^{2}$ & & 0,0042 & \\
\hline \multicolumn{4}{|c|}{ 91.640 Left-censored observations } \\
\hline 187.691 Uncensored obse & & & \\
\hline
\end{tabular}

pengeluaran berpemanis sebesar $\mathrm{Rp}$ 478,32 lebih besar daripada yang tidak pernah akses internet, sama halnya untuk tujuan media sosial memiliki rerata pengeluaran sebesar $\mathrm{Rp}$ 1.705,72 dibandingkan dengan bukan media sosial.

\section{Pembahasan}

\section{Usia}

Berdasarkan hasil OLS semakin bertambah usia maka pengeluaran ikut meningkat. Namun, menurut hasil analisis Probit semakin bertambah usia maka partisipasi kepala keluarga terhadap pengeluaran konsumsi minuman menurun. Sebuah penelitian menyebutkan bahwa tren konsumsi minuman berpemanis cenderung menurun seiring dengan bertambahnya usia, kelompok usia 15-24 tahun mengkonsumsi minuman berpemanis lebih tinggi sedangkan kelompok usia 65 tahun ke atas lebih sedikit mengkonsumsi minuman berpemanis (Manyema dkk, 2015).

Penelitian pada mahasiswa tingkat I yang diperkirakan berusia sekitar 17-18 tahun mengkonsumsi minuman berkalori tinggi dengan frekuensi konsumsi tinggi yang sebanyak 64\% (Masri, 2018). Usia di atas 50 tahun mulai mengurangi konsumsi minuman berpemanis berlebih hal ini dikarenakan mereka mulai menyadari bahaya penyakit PTM di usia lansia, hal ini didukung oleh penelitian Ramadhani \& Mahmudiono (2018) yang melihat ada hubungan antara konsumsi minuman berpemanis terhadap kejadian diabetes mellitus pada kelompok lansia dimana berisiko 9.375 kali (Ramadhani dan Mahmudiono, 2018).

\section{Jenis Kelamin}

Laki-laki meningkatkan pengeluaran untuk konsumsi 
minuman berpemanis dan partisipasi lebih tinggi dibandingkan dengan perempuan. Sebuah penelitian menyebutkan bahwa perempuan mengkonsumsi minuman berpemanis lebih sedikit dibandingkan laki-laki yaitu sebesar 68,24\% (Harvard University, 2009). Sejalan dengan SHANG et al (2012) yang menyebutkan bahwa laki-laki khususnya usia 6-13 tahun lebih banyak mengkonsumsi minuman berpemanis sebesar 52,1\% dibandingkan dengan perempuan yang hanya mengkonsumsi sebesar 39,9\%.

\section{Status Perkawinan}

Kepala keluarga yang berstatus kawin meningkatkan pengeluaran untuk konsumsi minuman berpemanis dan partisipasi lebih tinggi dibandingkan dengan yang berstatus tidak kawin. Menurut Maynard Keynes, rumah tangga yang memiliki pendapatan tinggi cenderung mengkonsumsi lebih banyak. Ada korelasi yang kuat antara pendapatan dan konsumsi oleh sebab itu pendapatan merupakan penentu utama berapa banyak orang memilih untuk mengkonsumsi (Mankiw, 2009). Sesuai dengan hasil penelitian ini, individu yang berstatus kawin berpeluang memiliki pengeluaran dan partisipasi konsumsi minuman berpemanis. Jika dilihat lebih lanjut pada Tabel 5 persentase yang bekerja lebih besar artinya peluang untuk menghasilkan pendapatan melalui hasil upah/ gaji yang diperoleh semakin baik, maka dari itu kecenderungan untuk konsumsi lebih besar.

Tabel 5 Analisis Lanjut antara Status Pekerjaan dengan Status Perkawinan

\begin{tabular}{lccc}
\hline & \multicolumn{3}{c}{ Status Pekerjaan } \\
\cline { 2 - 4 } & Bekerja (\%) & $\begin{array}{c}\text { Selain } \\
\text { Bekerja (\%) }\end{array}$ & $\begin{array}{c}\text { Total } \\
(\%)\end{array}$ \\
\hline Kawin & 91,94 & 8,06 & 100 \\
Belum & 65,82 & 34,18 & 100 \\
Kawin & & & \\
\hline
\end{tabular}

\section{Tingkat Pendidikan}

Tingkat pendidikan kepala keluarga kategori SD, SMP, dan SMA meningkatkan pengeluaran dan partisipasi konsumsi minuman berpemanis lebih tinggi dibandingkan dengan yang tidak bersekolah. Namun, kepala keluarga dengan tingkat pendidikan perguruan tinggi, menunjukkan ada yang meningkatkan pengeluaran dan menurunkan partisipasi konsumsi minuman berpemanis dibandingkan dengan yang tidak bersekolah.

Kepala keluarga merupakan seseorang yang penting dalam mengambil suatu keputusan dalam memilih ingin mengkonsumsi atau tidak terhadap suatu barang. Menurut penelitian Tasevska dkk (2017)frekuensi konsumsi minuman berpemanis paling tinggi pada orang tua dengan tingkat pendidikan tinggi dan orang tua yang konsumsi minuman berpemanis. Demikian pula, penelitian yang dilakukan oleh SHANG dkk (2012) yang menyebutkan bahwa anak-anak yang memiliki orang tua dengan tingkat pendidikan rendah cenderung lebih rentan untuk mengkonsumsi minuman berpemanis tinggi. Penelitian lain menyebutkan bahwa anak-anak dari ibu yang memiliki tingkat pendidikan rendah lebih banyak mengkonsumsi minuman berpemanis dibandingkan dengan ibu yang memiliki tingkat pendidikan tinggi hal ini dipengaruhi oleh ketersediaan minuman berpemanis di rumah (Ansem dkk, 2014).

\section{Status Pekerjaan}

Kepala keluarga yang berstatus bekerja meningkatkan pengeluaran dan partisipasi konsumsi minuman berpemanis lebih tinggi dibandingkan dengan yang berstatus bukan bekerja. Semakin banyak penduduk usia kerja/produktif maka akan semakin besar tingkat konsumsi. Apabila jika dari hasil pekerjaan tersebut menghasilkan upah/ gaji yang baik maka semakin banyak penduduk bekerja akan semakin besar penghasilannya (Rahardja dan Manurung, 2017).

\section{Wilayah Tempat Tinggal}

Responden yang tinggal di perkotaan meningkatkan pengeluaran dan partisipasi konsumsi minuman berpemanis lebih tinggi dibandingkan di pedesaan. Hasil analisis lanjut diketahui bahwa akses internet untuk terpapar informasi seputar iklan kesehatan ataupun makanan dan minuman, di perkotaan lebih tinggi dibandingkan dengan di pedesaan yaitu 71,25\%.

\begin{tabular}{|c|c|c|c|}
\hline \multicolumn{4}{|c|}{ Wilayah Tempat Tinggal Tahun 2017} \\
\hline & \multicolumn{2}{|c|}{ Akses Internet } & \multirow[t]{2}{*}{ Total } \\
\hline & Ya & Tidak & \\
\hline & $\%$ & $\%$ & $\%$ \\
\hline Pedesaan & 28,75 & 62,58 & 100 \\
\hline Perkotaan & 71,25 & 37,42 & 100 \\
\hline
\end{tabular}

Apabila dikaitkan dengan akses terhadap konsumsi minuman berpemanis, wilayah perkotaan memiliki peluang besar terhadap pengeluaran konsumsi. Berdasarkan faktor-faktor yang memengaruhi tingkat konsumsi, semakin banyak penduduk yang tinggal di wilayah perkotaan maka kecenderungan mempunyai pengeluaran untuk konsumsi semakin 
tinggi karena pola hidup di wilayah perkotaan lebih konsumtif (Rahardja dan Manurung, 2017). Faktor lain seperti terpaparnya rumah tangga terhadap informasi kesehatan juga akan memengaruhi tingkat konsumsi. Seperti halnya media iklan dengan intervensi slogan dan musik yang menarik, serta melibatkan aktris/aktor TV ataupun tokohtokoh olahraga yang terkenal dapat memengaruhi masyarakat khususnya anak-anak untuk mencoba produk-produk baru minuman berpemanis (Battram dkk, 2016). Rumah tangga yang terpapar iklan dan tertarik terhadap produk minuman berpemanis berpeluang untuk meningkatkan pengeluaran konsumsi dan hal ini tidak menutup kemungkinan untuk munculnya penyakit tidak menular akibat konsumsi minuman berpemanis berlebihan. Berdasarkan prevalensi kejadian obesitas di Indonesia berdasarkan profil kesehatan kesehatan Indonesia tahun 2017 berdasarkan tempat tinggal diketahui bahwa prevalensi obesitas di daerah perkotaan lebih tinggi yaitu sebesar $38.3 \%$ dibandingkan daerah perdesaan yaitu sebesar 28.2\% (Kemenkes RI, 2018).

\section{Status Ekonomi}

Pada kuintil 1 dan 2 akan menurunkan pengeluaran dan partisipasi konsumsi minuman berpemanis dibandingkan dengan pada kuintil 3. Sedangkan pada kuintil 4 dan 5 meningkatkan pengeluaran dan partisipasi konsumsi minuman berpemanis dibandingkan kuintil 3. Semakin tinggi tingkat pendapatan, maka daya beli semakin kuat dan menyebabkan permintaan terhadap konsumsi meningkat (Rahardja dan Manurung, 2017). Dibandingkan dengan kuintil 3, kuintil 1 dan 2 termasuk status ekonomi rendah maka jika pengeluaran terhadap konsumsi minuman berpemanis menurun hal ini dikarenakan pendapatan yang cenderung kecil sehingga kemampuan daya beli tidak sebaik pada kuintil 4 dan 5 . Namun, hal berbeda dari hasil penelitian SHANG dkk (2012) yang menyebutkan bahwa anak-anak yang memiliki pendapatan keluarga yang rendah cenderung untuk memiliki proporsi konsumsi minuman berpemanis lebih tinggi.

\section{Akses Internet dan Tujuan Akses Internet}

Variabel akses internet di rumah tangga diperoleh hasil bahwa rumah tangga yang pernah mengakses internet menurunkan pengeluaran dan partisipasi konsumsi minuman berpemanis dibandingkan dengan yang tidak pernah mengakses internet.
Sedangkan tujuan akses internet untuk media sosial menurunkan pengeluaran untuk konsumsi minuman berpemanis tetapi meningkatkan partisipasi dibandingkan dengan tujuan bukan untuk media sosial.

Internet adalah suatu jaringan komunikasi bersifat elektronik yang bertujuan untuk menghubungkan jaringan komputer dengan fasilitas komputer dimana sudah terorganisasi melalui telepon atau satelit di seluruh dunia (KBBI, 2019). Akses terhadap media sosial merupakan salah satu manfaat penggunaan internet. Media sosial adalah suatu media yang memungkinkan pengguna untuk melakukan berbagai hal terutama membuat dan berbagi informasi dalam jaringan sosial (Kemendikbud RI, 2019). Penelitian Masri (2018) menyebutkan bahwa iklan minuman dari berbagai media berpengaruh terhadap perilaku mengkonsumsi minuman berkalori tinggi dimana hampir seluruh individu penelitian lebih banyak mengkonsumsi minuman tersebut (96.4\%). Anakanak rentan terpengaruh terhadap iklan-iklan yang menarik dalam memilih minuman berpemanis (Battram dkk, 2016). Iklan akan memengaruhi preferensi responden terhadap minuman berpemanis dan lebih tinggi pada responden yang berada dalam lingkungan obesogenic (Gesualdo dan Yanovitzky, 2019).

\section{Kebijakan Terkait Minuman Berpemanis}

Kebijakan terkait minuman berpemanis di Indonesia terdapat Permenkes RI Nomor 30 tahun 2013 yang menyebutkan bahwa konsumsi gula apabila melebihi batas lebih dari 50 gram per orang per hari akan berisiko terkena hipertensi, stroke, diabetes, dan serangan jantung (Kemenkes RI, 2013a) sedangkan Peraturan BPOM Nomor 30 Tahun 2018 mencantumkan jumlah pangan yang wajar dikonsumsi per orang per hari (BPOM RI, 2018). Kebijakan di luar negeri salah satunya adalah penerapan pajak minuman berpemanis. Penelitian Waterlander dkk (2014) menyebutkan bahwa pajak 6-19\% cukup efektif mengurangi pembelian minuman berpemanis. Manyema dkk (2014) menyatakan bahwa dengan pajak 20\% asupan energi karena konsumsi minuman berpemanis diperkirakan turun sebanyak $36 \mathrm{~J}$ dan kejadian obesitas menurun sekitar 3,8\% pada laki-laki dan 2,4\% pada perempuan. Sementara Manyema dkk (2015) menunjukkan bahwa kasus insiden diabetes dapat berkurang dengan adanya pajak 20\% meskipun membutuhkan waktu cukup lama. 
Menurut data Riskesda tahun 2013, masalah kelebihan berat badan dan obesitas paling besar pada usia 5-12 tahun yaitu sebesar 10,8\% karena kelebihan berat badan dan sebesar 8,8\% karena obesitas (Kemenkes RI, 2013b). Jika dari sisi kesehatan, penerapan pajak minuman berpemanis dapat dipertimbangan untuk diterapkan di Indonesia. UU Nomor 39 Tahun 2007 tentang cukai menyebutkan bahwa salah satu sifat atau karakteristik barang yang dapat dikenakan cukai adalah apabila pemakaiannya dapat menimbulkan dampak negatif bagi masyarakat atau lingkungan hidup (Republik Indonesia, 2007). Selain pajak minuman berpemanis, peraturan mengenai kebijakan promosi minuman berpemanis di media massa perlu diperhatikan. Sebab, promosi dalam bentuk iklan suatu produk minuman akan memengaruhi konsumen dalam memilih.

\section{Kesimpulan dan Saran}

Proporsi pengeluaran rumah tangga untuk konsumsi minuman berpemanis cukup besar yaitu 67,19\% dari total responden yaitu 279.331 rumah tangga. Berdasarkan hasil penelitian didapatkan bahwa variabel akses internet merupakan variabel yang konsisten memiliki probabilitas menurunkan pengeluaran dan partisipasi rumah tangga untuk konsumsi minuman berpemanis. Variabel usia, jenis kelamin, status perkawinan, pendidikan, pekerjaan, wilayah tempat tinggal dan status ekonomi, cenderung konsisten memiliki probabilitas meningkatkan pengeluaran dan partisipasi rumah tangga untuk konsumsi minuman berpemanis. Hal yang dapat dilakukan adalah melakukan promosi dan sosialisasi iklan layanan kesehatan masyarakat terkait batasan konsumsi minuman berpemanis dan bahaya konsumsi minuman berpemanis berlebihan, dapat melalui media massa/elektronik, televisi, dan media sosial sehingga semua lapisan masyarakat dapat terpapar informasi tersebut. Serta pencantuman batas aman konsumsi gula minuman berpemanis pada kemasan.

\section{Referensi}

Ansem dkk. 2014. Socio-economic inequalities in children's snack consumption and sugar-sweetened beverage consumption: the contribution of home environmental factors. British Journal of Nutrition. Cambridge University Press. 112(03): 467-476. Battram dkk. 2016. Sugar-Sweetened Beverages: Children's Perceptions, Factors of Influence, and Sugges- tions for Reducing Intake. Journal of Nutrition Education and Behavior. 48(1): 27-34.e1.

Belotti dkk. 2015. twopm: Two-part models. Stata Journal.15(1): 3-20.

BPOM RI. 2018 Peraturan Badan Pengawas Obat dan Makanan Nomor 30 Tahun 2018 Tentang Angka Konsumsi Pangan. Jakarta.

CDC. 2018. Get the Facts: Sugar-Sweetened Beverages and Consumption, Centre of Disease Control and Prevention. Accessed: 26 November 2018 <https://www.cdc.gov/nutrition/data-statistics/ sugar-sweetened-beverages-intake.html>

Gesualdo dan Yanovitzky. 2019. Advertising Susceptibility and Youth Preference for and Consumption of Sugar-Sweetened Beverages: Findings from a $\mathrm{Na}$ tional Survey. Journal of Nutrition Education and Behavior. Elsevier Inc. 51(1): 16-22.

Gujarati. 2004. Basic Econometrics, in Basic Econometrics. Fourth. The McGraw-Hill Companies.

Harvard University. 2009. How Sweet Is It?. <https:// www.hsph.harvard.edu/nutritionsource/healthydrinks/sugary-drinks/how-sweet-is-it/>

$\mathrm{Hu}$ dan Malik. 2010. Physiology \& Behavior Sugar-sweetened beverages and risk of obesity and type 2 diabetes : Epidemiologic evidence. Physiology ef Behavior. Elsevier Inc., 100(1): 47-54.

KBBI. 2019. Definisi Internet. 6 January 2019 <https://kbbi.web.id/internet>

Kemendikbud RI. 2019. Definisi Media Sosial. 6 January 2019. <https://kbbi.kemdikbud.go.id/entri/ internet>

Kemenkes RI. 2013a. Peraturan Menteri Kesehatan Republik Indonesia Nomor 30 Tahun 2013 Tentang Pencantuman Informasi Kandungan Gula, Garam, dan Lemak Serta Pesan Kesehatan untuk Pangan Olahan dan Pangan Siap Saji.

Kemenkes RI. 2013b. Riset Kesehatan Dasar Riskesdas 2013. Jakarta.

Kemenkes RI. 2018. Profil Kesehatan Indonesia Tahun 2017. Jakarta.

Manyema dkk. 2014. The potential impact of a 20\% tax on sugar-sweetened beverages on obesity in South African adults: a mathematical model. PloS one. 9(8): e 105287.

Manyema dkk. 2015. Decreasing the Burden of Type 2 Diabetes in South Africa: The Impact of Taxing Sugar-Sweetened Beverages. PloS one. Edited by P. H. M. van Baal, 10(11): e0143050.

Masri, E. 2018. Faktor Determinan Perilaku Konsumsi Minuman Berkalori Tinggi pada Mahasiswa. Jurnal 
Farmasi dan Kesehatan. 8(2): 53-63.

Rahardja dan Manurung. 2017. Pengantar Ilmu Ekonomi (Mikroekonomi dan Makroekonomi) Edisi Ketiga. Ketiga. Jakarta: Lembaga Penerbit Fakultas Ekonomi Universitas Indonesia.

Ramadhani dan Mahmudiono. 2018. Hubungan Konsumsi Sugar-Sweetened Beverages dengan Kejadian Diabetes Melitus pada Lansia. Media Gizi Indonesia. 13: 49-56.

Republik Indonesia. 2007. Undang-Undang Republik Indonesia Nomor 39 Tahun 2007 Tentang Perubahan Atas Undang-Undang Nomor 11 Tahun 1995 Tentang Cukai.

SHANG dkk. 2012. Report on Childhood Obesity in China (9): Sugar-sweetened Beverages Consumption and Obesity. Biomedical and Environmental Sciences. 25(2):125-132.

Siswanto dkk. 2014. Buku Studi Diet Total: Survei Konsumsi Makanan Individu Indonesia 2014. Jakarta. Edited by D. K. Trihono, Atmarita, Abas Basuni Jahari. Badan Penelitian dan Pengembangan Kesehatan 2014.

Tasevska dkk. 2017. Determinants of Sugar-Sweetened Beverage Consumption among Low-Income Children: Are There Differences by Race/Ethnicity, Age, and Sex? Journal of the Academy of Nutrition and Dietetics. Elsevier Inc. 117(12):1900-1920.
Trivedi, A. C. C. P. 2009. Microeconometrics Using Stata. Stata Press.

U.S. Department of Health and Human Services and U.S. Department of Agriculture. 2015. Dietary Guidelines For Americans 2015-2020 Eight Edition. XIII. DietaryGuidlines.gov.

Waterlander dkk. 2014. Effects of a price increase on purchases of sugar sweetened beverages. Results from a randomized controlled trial. Appetite. 78: 32-9.

WHO. 2018a. Noncommunicable diseases, World Health Organization. 12 September 2018. <http:// www.who.int/en/news-room/fact-sheets/detail/ noncommunicable-diseases (Accessed:) >

WHO. 2018b. Noncommunicable Diseases Country Profiles 2018. Geneva. doi: Licence: CC BY-NCSA 3.0 IGO.

WHO. 2018c. Obesity and overweight, World Health Organization. 27 August 2018. <http://www. who.int/news-room/fact-sheets/detail/obesity-and-overweight>

WHO. 2018d. Reducing free sugars intake in children and adults, e-Library of Evidence for Nutrition Actions (eLENA). 26 November 2018. <https:// www.who.int/elena/titles/guidance_summaries/ sugars_intake/en/>. 